Our Nature (2011) 9: 89-99

\title{
Phenology of Leaf Flushing, Flower Initiation and Fruit Maturation in Dry Deciduous and Evergreen Forests of Bhadra Wildlife Sanctuary, Karnataka, Southern India
}

\author{
A. Nanda ${ }^{1 *}$, H.M. Prakasha ${ }^{1}$, Y.L. Krishna Murthy ${ }^{1}$ and H.S. Suresh ${ }^{2}$ \\ ${ }^{1}$ Department of PG studies and Research in Applied Botany, Bioscience Complex, Jnana Sahyadri \\ Kuvempu University, Shankaraghatta, Shimoga- 577 451, Karnataka, India \\ ${ }^{2}$ Center for Ecological Sciences, Indian Institute of Science, Bangalore- 560 012, Karnataka, India \\ "E-mail:nandabotany@gmail.com
}

Received: 13.10.2010, Accepted: 28.11.2011

\begin{abstract}
Varying with altitude and rainfall of two forest types of tropical forest were studied. Community wide pattern in both vegetative and reproductive phenophases among various tree species of Bhadra wildlife sanctuary, Karnataka is reported here. Leaf initiation peaks in the month of April in dry forest, after leaf less period of 1-2 months, in evergreen forest leaf initiation peaks in the month of January simultaneously with leaf senescence. Flower initiation begins from January till June with a peak in April in dry forest. Evergreen forest starts from November to march with a peak in January and February. Fruit maturation in dry forest starts from March to December with a peak in August and November, in evergreen forest from January to July with a peak in April.
\end{abstract}

Key words: Community-wide, tree phenophases, tropical forests, Western Ghats

\section{Introduction}

Tropical forest plant communities display various phenological patterns. Different forest types are considered to be indicators of the amount and annual distribution of rainfall (Walter, 1971), because seasonal variation in tree water status constitutes a major determinant of tropical tree phenology (Borchert et al., 2002). A variety of factors have been proposed to drive the phenology. These include abiotic factors such as rainfall, day length, irradiance, temperature and relative humidity (Wright and Van Schaik, 1994). Biotic factors are pollinators or seed dispersers (Rathke and Lacey, 1985), herbivory (Williams-Linera, 1999). Seasonal changes in abiotic and biotic factors can be expected to have consistent effects on phenology of tropical forests (Wright, 1996). There are several community wide studies on phenology (Murali and Sukumar, 1994; Justiniano and Fredericksen, 2000; McLaren and McDonald, 2003; Borchert et al., 2004; Singh and Kushwaha, 2005; Sundarapandian et al., 2005). Yet our understanding of phenophases in different forest types is scanty. Understanding of community wide patterns in phenophase is essential for understanding the functioning of ecosystem and scientific management of natural resources. This type of study will help to understand various phenophases in the global climatic change scenario at local level. 


\section{Study area}

The study was conducted in Bhadra Wildlife Sanctuary located in Chikmagalur and Shimoga districts $\left(13^{\circ} 25^{\prime}\right.$ and $13^{\circ} 50^{\prime} \mathrm{N}$, $75^{\circ} 15^{\prime}$ and $\left.75^{\circ} 50^{\prime} \mathrm{E}\right)$ of Karnataka. The dry deciduous forest (Umblebailu, $13^{\circ} 46^{\prime}$ to $13^{\circ} 52^{\prime} \mathrm{N}, 75^{\circ} 36^{\prime}$ to $\left.75^{\circ} 42^{\prime} \mathrm{E}\right)$. The altitude 690 to $750 \mathrm{~m}$ asl. The evergreen forest (Kemmangundi, $13^{\circ} 32^{\prime}$ to $13^{\circ} 40^{\prime} \mathrm{N}, 75^{\circ} 44^{\prime}$ to $\left.75^{\circ} 45^{\prime} \mathrm{E}\right)$. These forests area common around the hills and valleys of where the altitude ranges from 1400 to $2000 \mathrm{~m}$ msl. These forests are on the windward side of the Western Ghats. The rainfall of the Sanctuary ranges from 500 to $2000 \mathrm{~mm}$. The terrain is gently undulating with valleys and steep hillocks. Detailed geological account of the sanctuary is given by Parameswar (1996). Rainfall data for the dry forest was collected from meteorological station, Bhadra River Project. Whereas for evergreen forest rainfall data from the coffee estate. Annual rainfall in two forest types varies in evergreen forest $1561.1 \mathrm{~mm}$ and in dry forest $542 \mathrm{~mm}$ during the study period is shown in (Fig. 1).

\section{Vegetation}

Vegetation of the sanctuary varies from dry deciduous to evergreen forest. According to (Champion and Seth, 1968) the dry deciduous forests of Umblebailu are classified as 'southern dry mixed deciduous forests'. The characteristic tree species of this type are Terminalia paniculata, Anogeissus latifolia, Xylia xylocarpa, Cassia fistula, Albizzia lebbeck, Terminalia crenulata, Tectona grandis, Diospyros montana, Mitragyna parviflora and Pterocarpus marsupium.
Kemmangundi forests are classified as 'Tropical wet evergreen forests'. The characteristic tree species of this forest are Artocarpus integrifolia, Cinnamomum spp., Myristica malabarica, Litsea spp. Neolitsea zeylanica. Syzygium spp., Macaranga peltata, Trema orientalis, Actinodaphne hookeri, and Isonandra perrottetiana.

Detailed description of the study area can be found elsewhere (Raju and Hegde, 1995; Parameswar, 1996; Krishna murthy et al., 2010). The present study describes the certain phenological patterns of tropical tree communities in dry deciduous forest and evergreen forest at Bhadra Wildlife Sanctuary for 2 years during June, 2004 to May, 2006.

\section{Materials and methods}

One transects each in evergreen forest $(10$ $\mathrm{km})$ long and in dry deciduous forest $(2 \mathrm{~km})$ long was laid along the periphery of sanctuary for clear visibility of the tree canopy. A total of 177 individuals comprising of 47 tree species in site- I and 277 individuals comprising of 45 tree species in site-II all above $20 \mathrm{~cm}$ d.b.h (diameter at breast height) were identified using various regional floras (Yoganarasimhan et al., 1982; Saldhana, 1984-1996; Gamble and Fischer, 1998; Ramaswamy et al., 2001; Neginhal, 2004). The representative plant specimens were collected, deposited in the Herbarium of the department of Applied Botany, Kuvempu University. Identified individuals were marked with a unique tag numbers with clear visibility to facilitate re-location. These marked individuals were monitored for both vegetative (foliar) and reproductive phenological events such has for leaf 


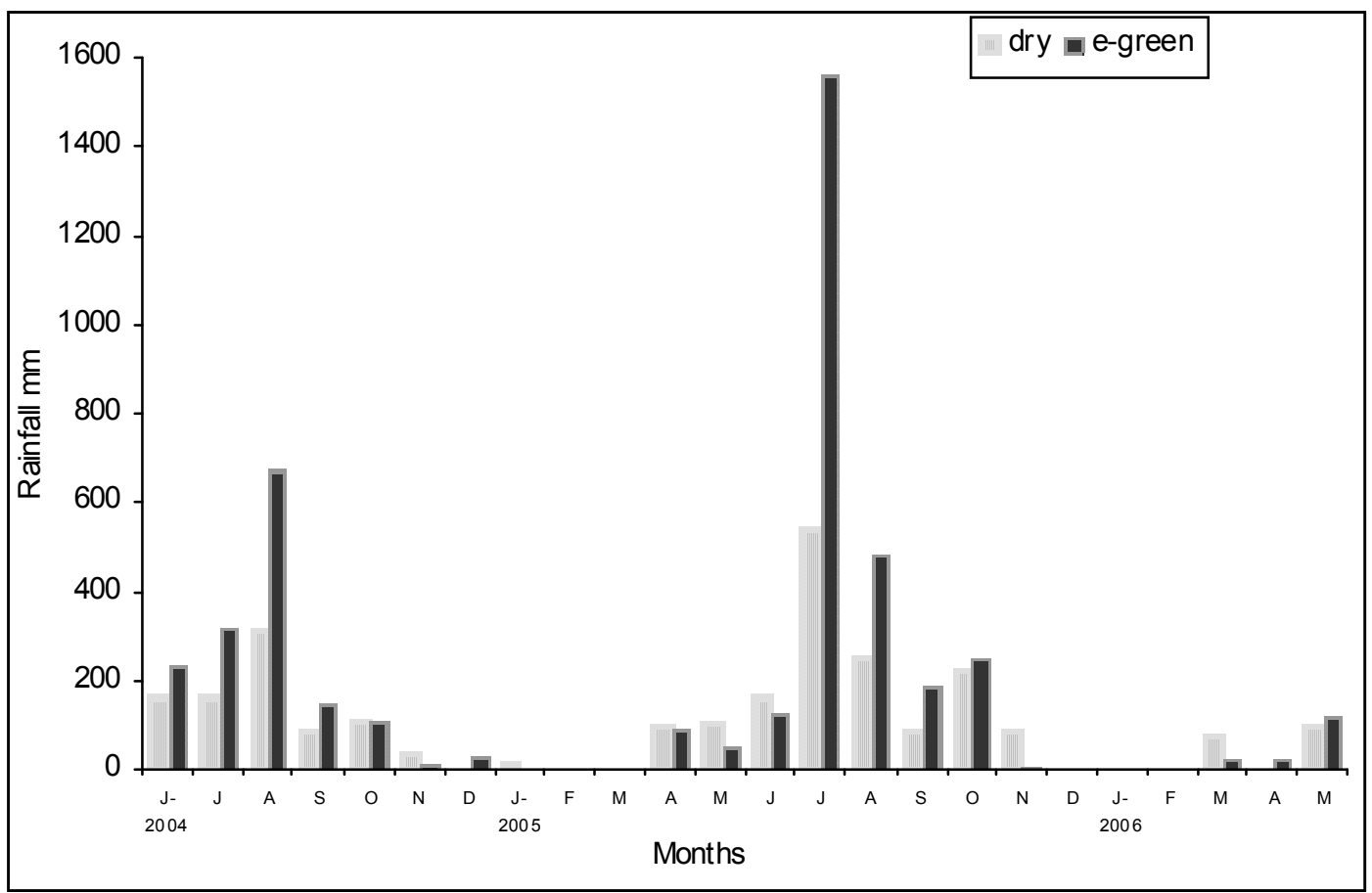

Figure 1. . Annual rainfall in dry and evergreen forest during the study period of Bhadra Wildlife Sanctuary.

flushing (LF2), flower budding (FL2) and fruit maturation (FR4) phenologies. Each stage in different categories of phenology was scored qualitatively with respect to both spread and intensity on canopy on a 0 to 100 scale.

\section{Data analysis}

Correlations analysis relating to rainfall parameter was computed. Differences in the patterns of frequency of leaf flushing, flower initiation and fruit maturation in a month between two forest types were analysed using the Kolmogorov-Smirnov test (KS test) and Chi-Square test (Zar, 2007).

\section{Results}

\section{Leaf initiation phenology}

Leaf initiation peaks in the month of April in dry forest, after leaf less period of 1-2 months. Whereas leaf initiation peaks in the month of January simultaneously along with leaf senescence in evergreen forest (Fig. 2).

\section{Factors influencing leaf flushing phenology}

In dry deciduous forest, Rainfall had significant negative influence on leaf flush during two month lag period $(\mathrm{r}=-0.62$, $\mathrm{p}<0.001)$ along with number of rainy days $(\mathrm{r}$ $=-0.61, p<0.002)$ It is clear from the (Fig. 3 ) that peak leaf flush happens two months before the peak in rainfall. However in evergreen forest, Rainfall had significantly negative influence on leaf flush during the corresponding months $(r=-0.41, p<0.04)$. Time lag correlations with rainfall were not significant either during one-month lag period or two-month lag period. Leaf flush peaks five months before the rainfall (Fig. $4)$. 
A. Nanda, H.M. Prakasha, Y.L. Krishna Murthy and H.S. Suresh/Our Nature (2011) 9:89-99

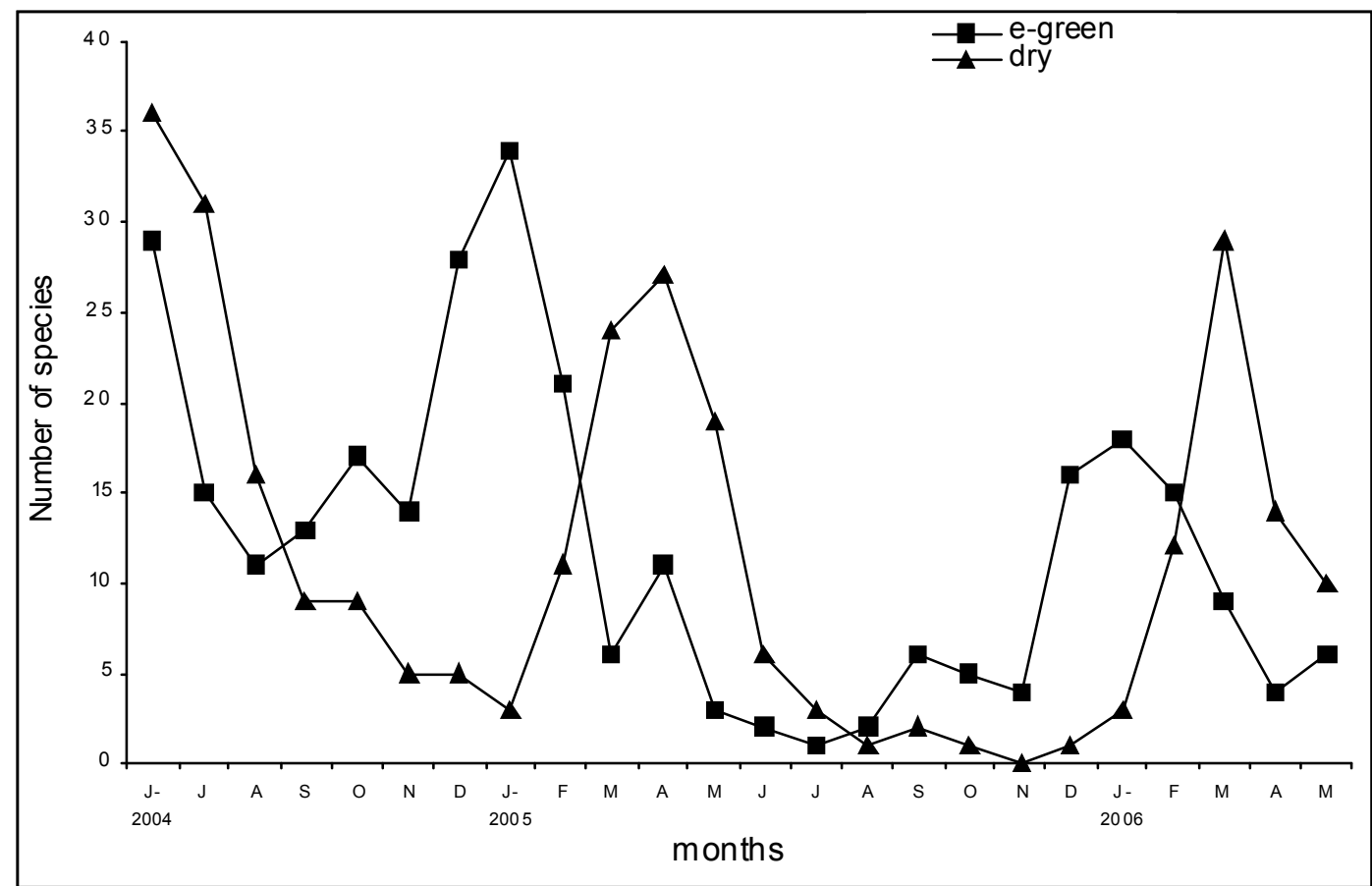

Figu re 2. Leaf flu shing in dry and evergreen forest of Bhadra Wildlife Sanctuary.

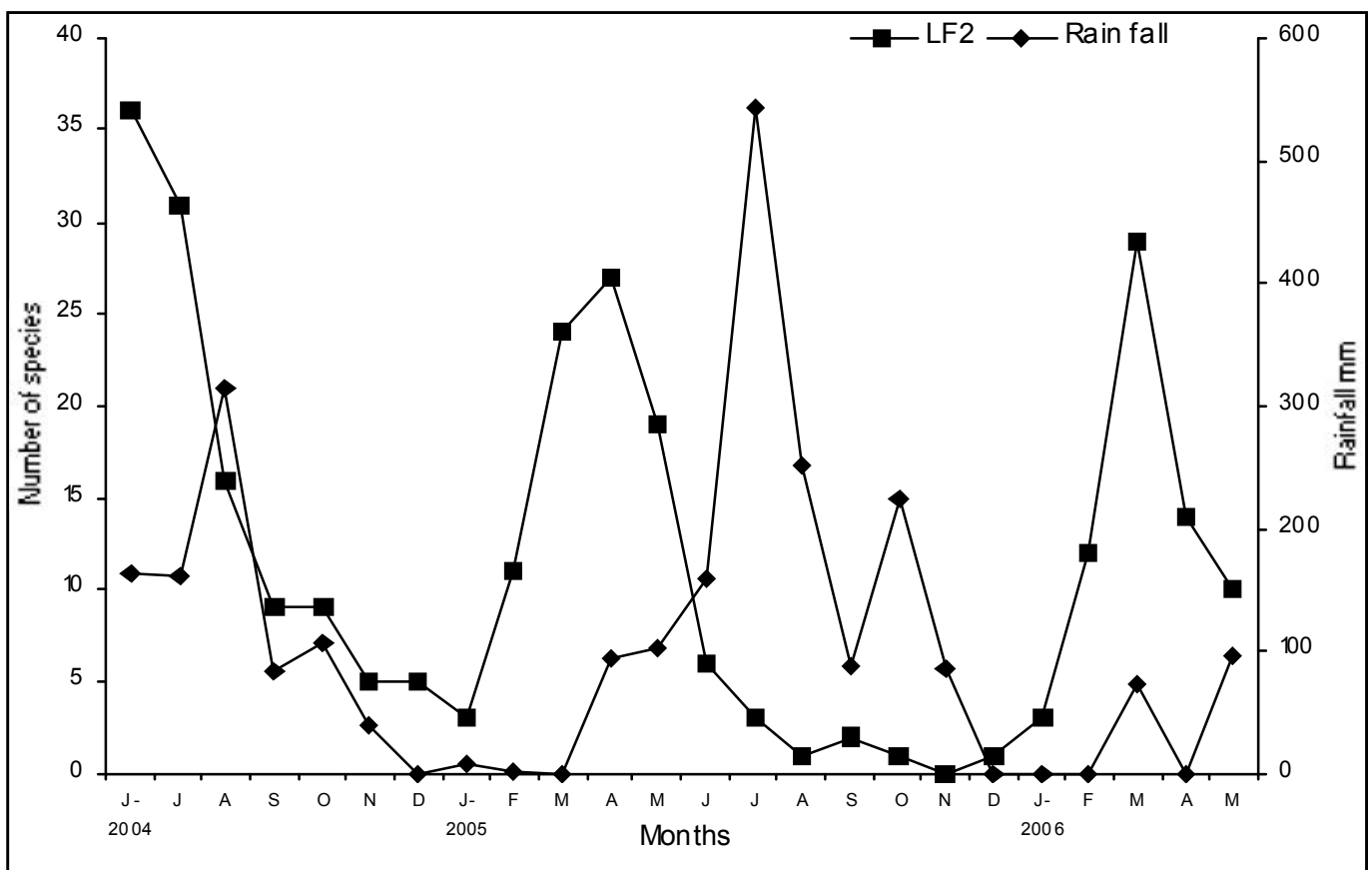

Figure 3. Leaf flushing and rainfall in dry forest of Bhadra Wildlife Sanctuary. 
A. Nanda, H.M. Prakasha, Y.L. Krishna Murthy and H.S. Suresh/Our Nature (2011) 9:89-99

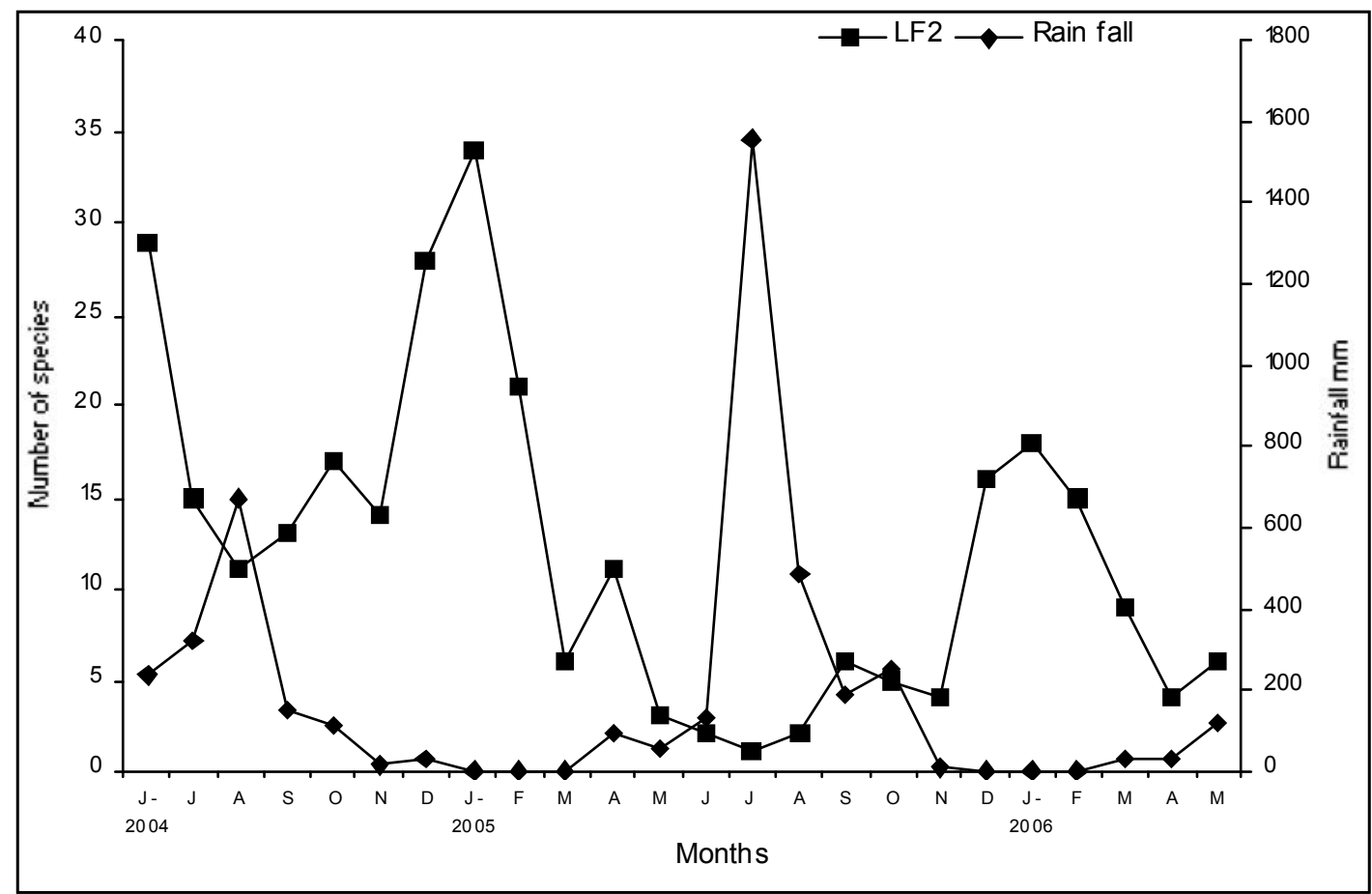

Figure 4. Leaf flushing and rainfall in evergreen forest of Bhadra Wildlife Sanctuary.

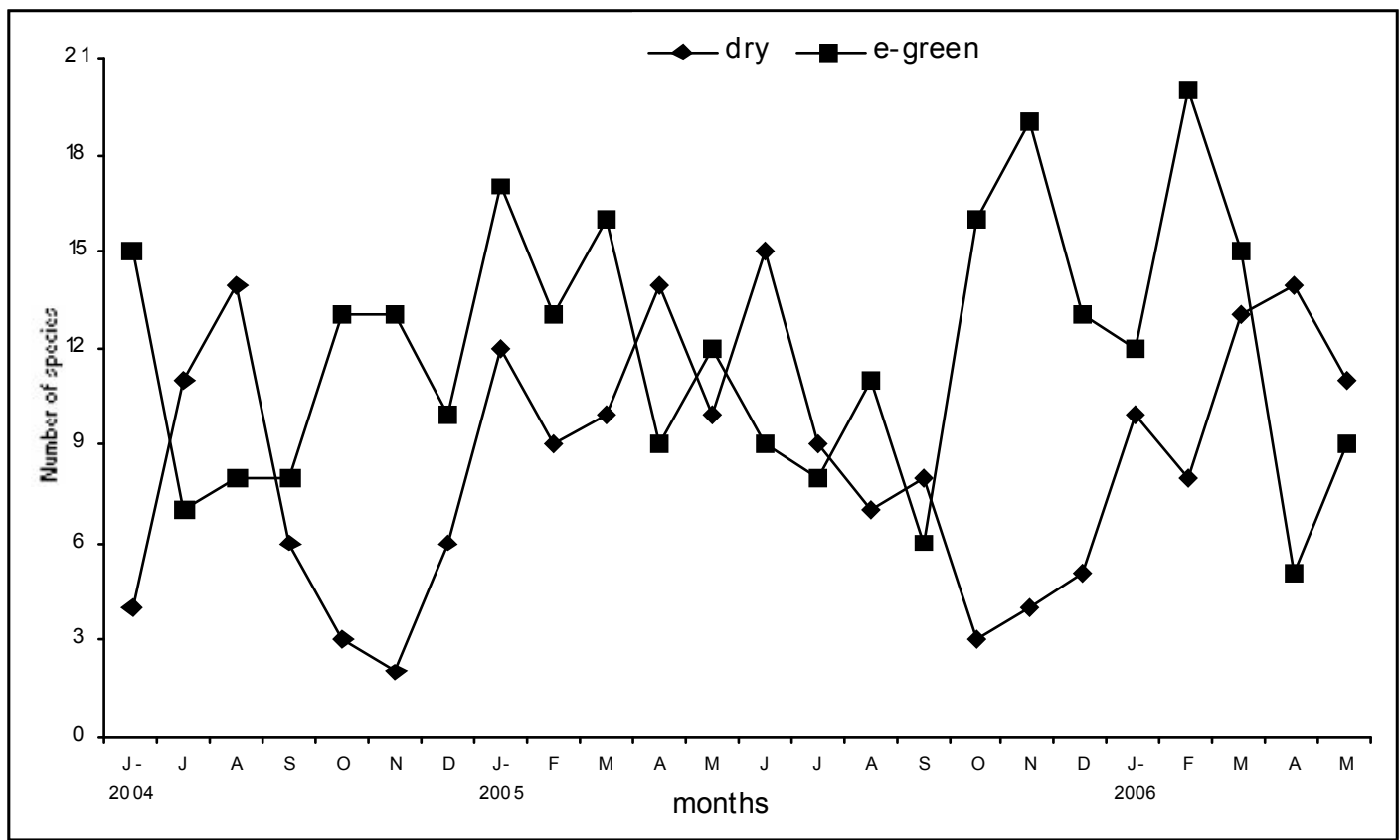

Figure 5. Flower budding in dry and evergreen forest of Bhadra Wildlife Sanctuary. 


\section{Flower phenology}

Flower initiation begins from January till June with a peak in April, i.e., most species initiate flowering in leafless period and few species simultaneously leafing and flowering in summer period. But the pattern in evergreen forest starts from November to march with a peak in January and February in post-winter to pre-summer (Fig. 5).

\section{Factors influencing flower initiation phenology}

In dry deciduous forest flowers initiation during two month lag period. Rainfall $(\mathrm{r}=$ $0.49, \mathrm{p}<0.02)$, and number of rainy days $(\mathrm{r}=$ $-0.57, \mathrm{p}<0.005$ ) during corresponding month had a significant negative influence.

Most of the species initiate flower during dry season in dry deciduous forest. It is also clear from the figure that the initiation begins in January and continues till June with peaks during April to June. Leaf initiation and flower initiation coincide (Fig. 6). But some of the species do initiate flower while having senescent leaves or during the leafless period. In dry deciduous forest some trees had leaf initiation and flower initiation coincide with each other (KS test $\mathrm{D}=0.2916, \mathrm{P}>0.10)$. In dry deciduous forest leafing and flowering events had taken place simultaneously. ChiSquare $\left(\chi^{2}=83.74, \mathrm{df}=23, \mathrm{p}<0.0001\right)$ is highly significant.

Whereas in evergreen forest rainfall during the corresponding months has a significant negative influence on the initiation of flowers among the species $(\mathrm{r}=$ $0.57, \mathrm{p}<0.003)$. Time lag correlations are not significant. Flower initiation and leaf flush happens simultaneously among the species (KS test, $\mathrm{D}=0.333, \mathrm{p}>0.10$ ), though in some months there are more number of species initiating flowers than having young leaves Chi-Square $\left(\chi^{2}=71.87, \mathrm{p}<0.0001, \mathrm{~N}\right.$ $=23$ ) is highly significant (Fig. 7).

\section{Fruiting phenology}

Fruit maturation in dry forest starts from March to December with a peak in August and November. From summer periods to end of rainy season. Whereas in evergreen forest from January to July with a peak in April i.e., fruit maturation in evergreen forest starts from onset of winter to a peak rainfall (Fig. 8).

\section{Factors influencing fruit maturation phenology}

In dry forest number of rainy days had a significant negative influence on maturity of fruits during corresponding months. Multiple regression during one month lag period was significant $(\mathrm{r}=0.65, \mathrm{~F}=3.43$, $\mathrm{p}<0.02$ ) with number of rainy days and rainfall influencing the event. Step wise regression was also significant $(\mathrm{r}=0.65, \mathrm{~F}=$ $4.82, \mathrm{p}<0.01$ ) with number of rainy days and rainfall influencing the event. Though rainfall influences maturity of fruits, it did not have significant impact on the maturity of fruits (Fig. 9).

Similar pattern was observed with maturity of fruits in evergreen forest also. Correlation during corresponding month was not significant with respect to fruit maturity (Fig. 10). Time lag correlations were negatively significant $(\mathrm{r}=-0.66$, $\mathrm{p}<0.004$, one-month lag $) \quad(\mathrm{r}=-0.64$, $\mathrm{p}<0.001$, two-month lag).

\section{Discussion}

Dry periods in tropical dry forests are characterized by intense physiological activities. Most of the phenological 


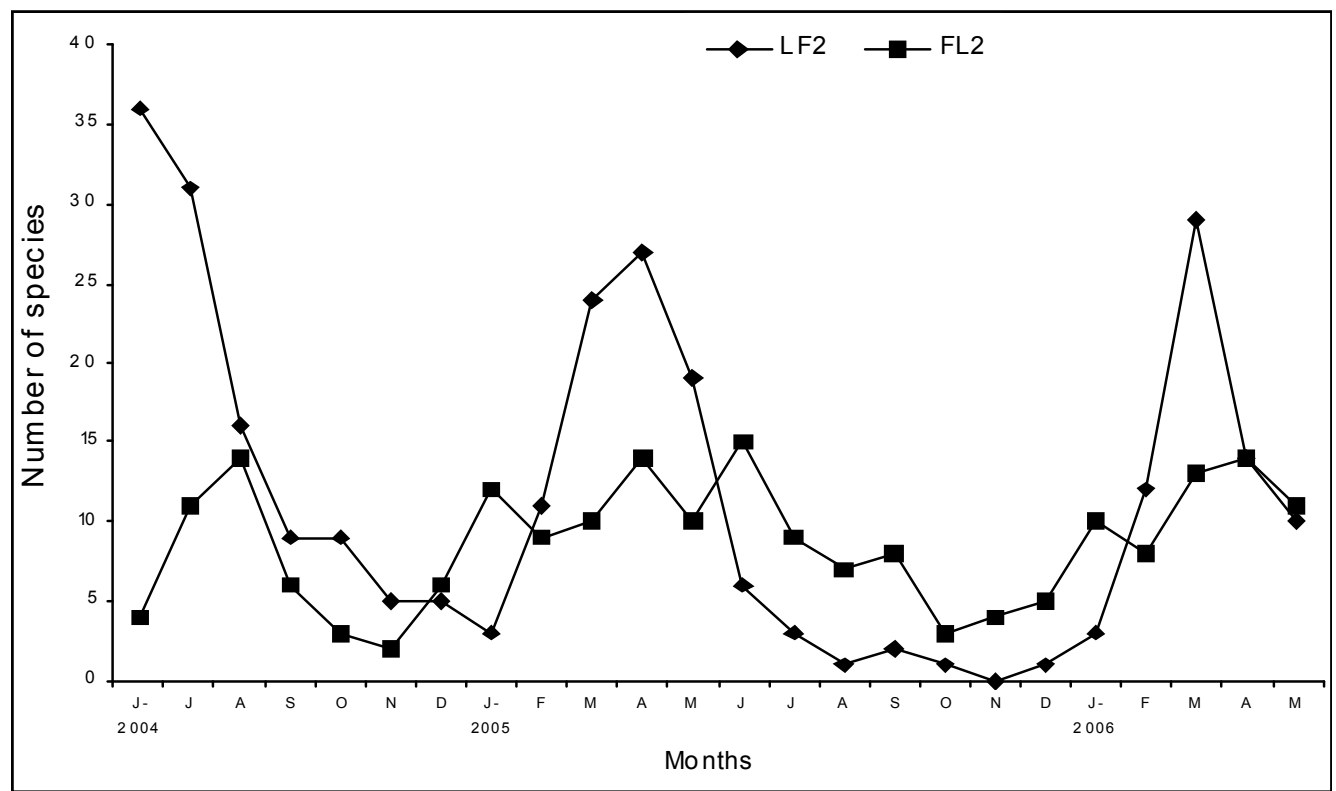

Figure 6. Leaf flushing and flower budding in dry forest of Bhadra Wildlife Sanctuary.

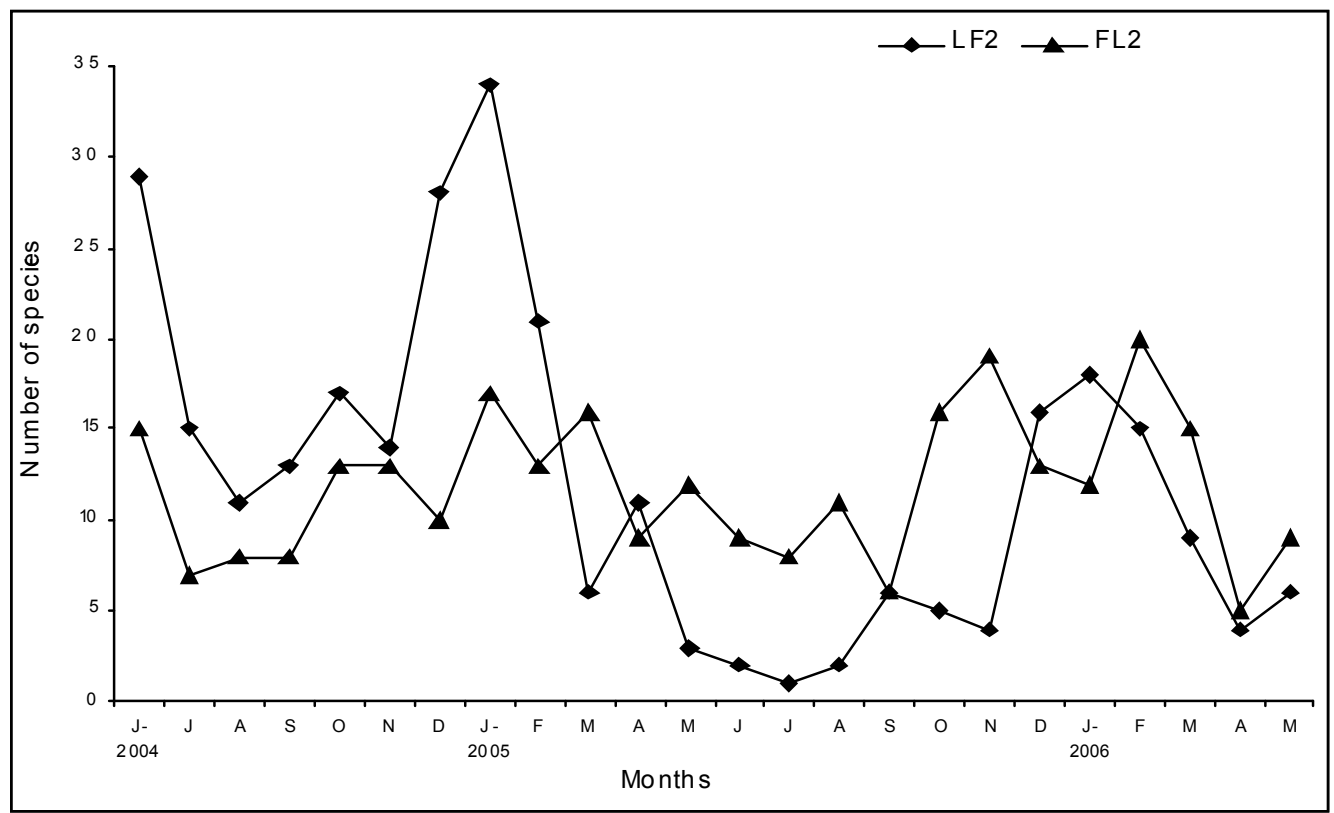

Figure 7. Leaf flushing and flower budding in evergreen forest of Bhadra Wildlife Sanctuary.

activities happen during the early of the dry set of rains in evergreen forest of season in evergreen forest and in dry season Kemmangundi. This synchronization in dry forest. In this present study leaf between senescence and flushing ensures flushing and leaf fall happens before the on that trees were never totally leafless. This 
A. Nanda, H.M. Prakasha, Y.L. Krishna Murthy and H.S. Suresh/Our Nature (2011) 9:89-99

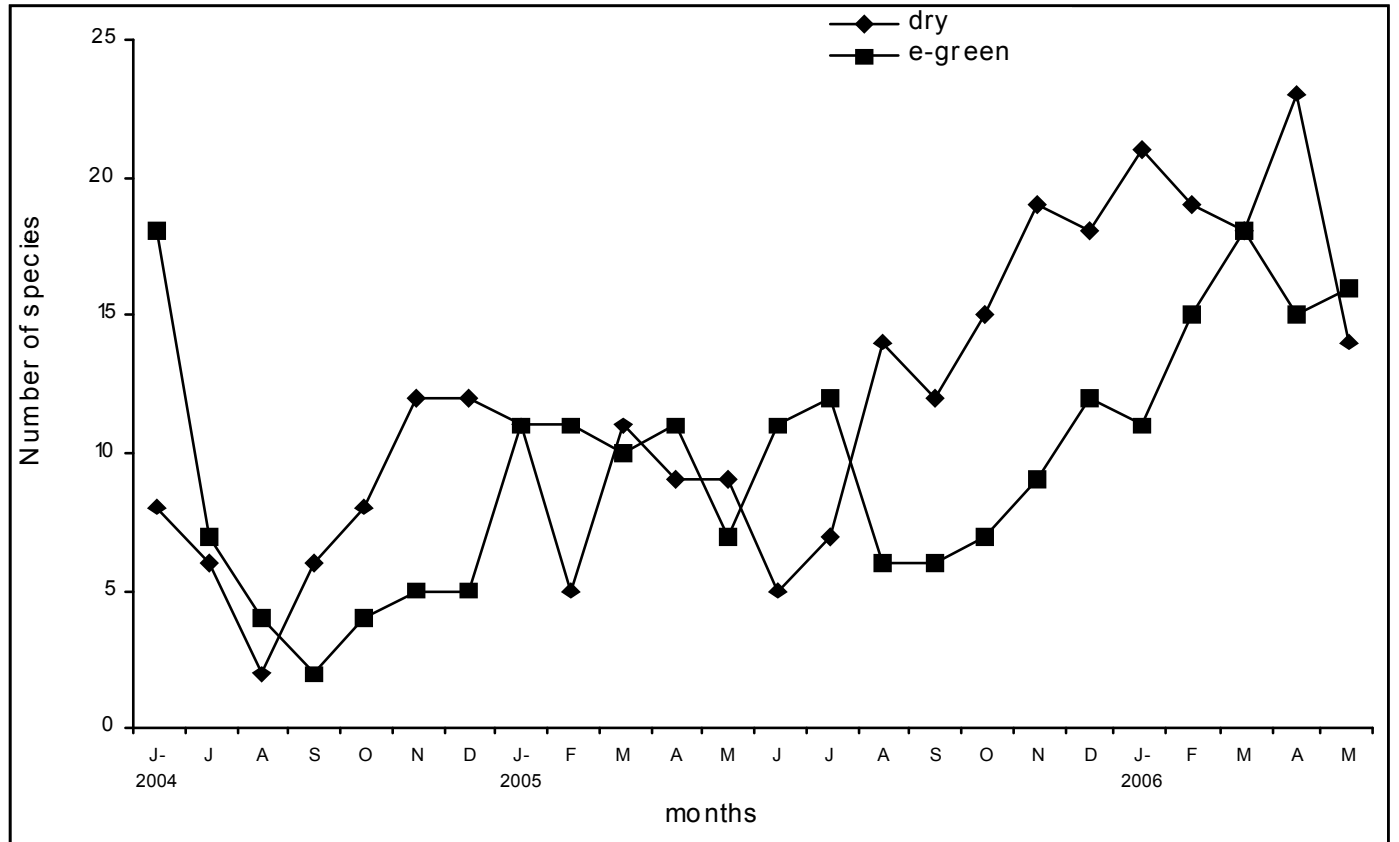

Figure 8. Fruit maturation in dry and evergreen forest of Bhadra Wildlife Sanctuary.

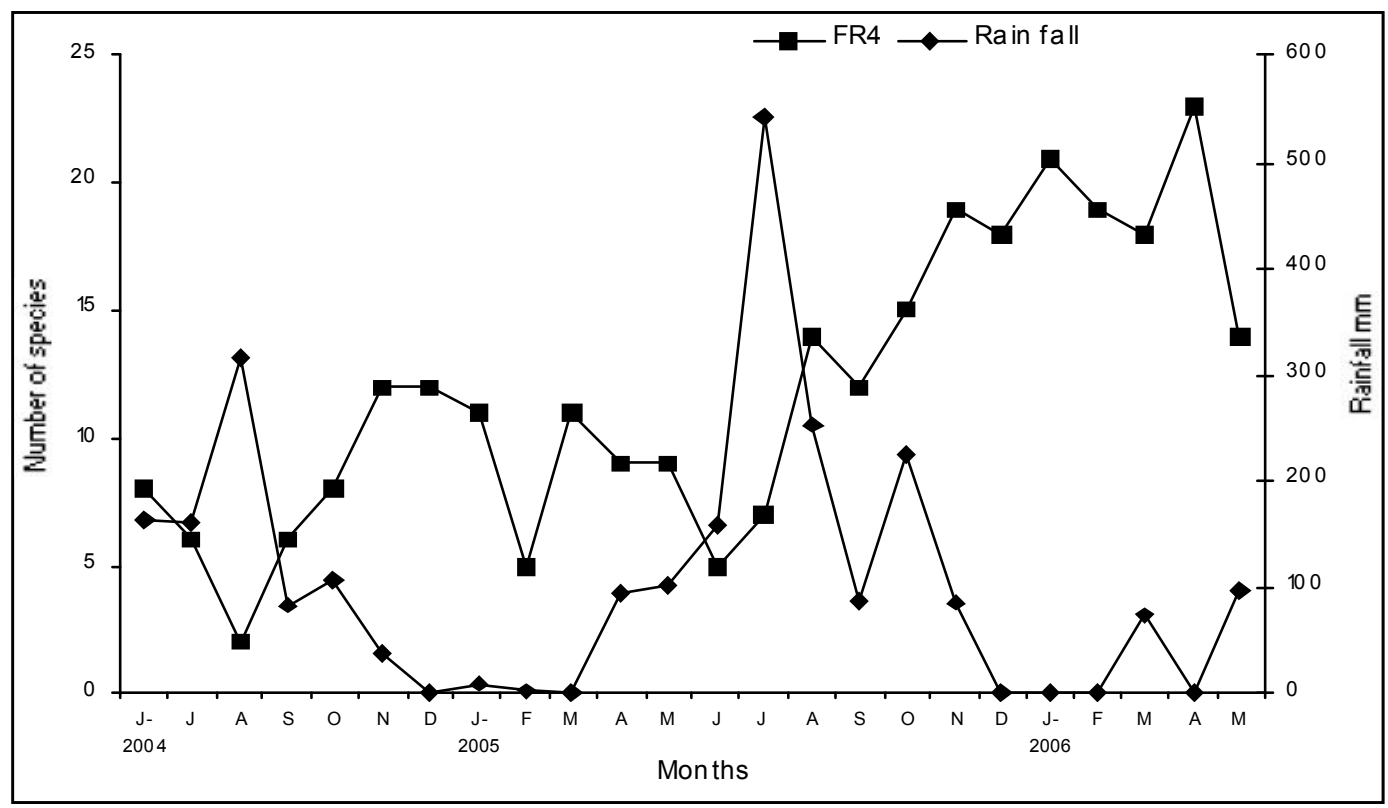

Figure 9. Fruit maturation and rainfall in dry forest of Bhadra Wildlife Sanctuary.

pattern is similar to other studies (Shukla and Ramakrishnan, 1982; Ralhan et al., 1985; Bhat, 1992; Saha, 2007).
However in dry forest leaf flushing is in dry season after a 1 to 2 month of leafless period, i.e., before the onset of rains is in 


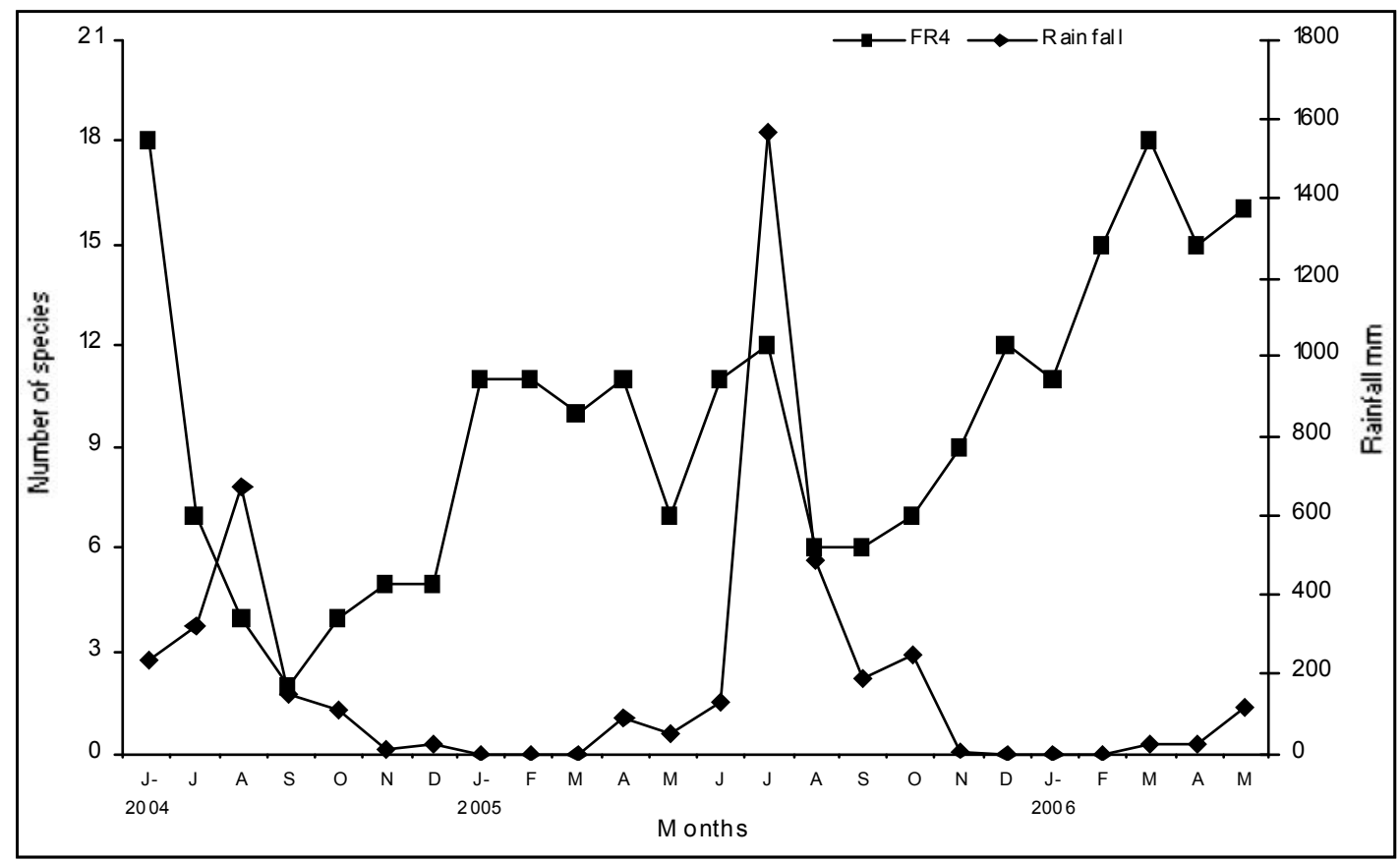

Fig. 10. Fruit maturation and rainfall in evergreen forest of Bhadra Wildlife Sanctuary.

agreement with other observation major abiotic factor controlling the timing, (Justiniano and Fredericksen, 2000; intensity and duration of flowering and Kushwaha and Singh 2005).

Flower initiation also differs with respect to forest type in this study. As evergreen trees initiated flowering in the winter period is similar to other studies (Bhat, 1992; Sundarapandian et al., 2005; Saha, 2007). Whereas in dry forest trees initiated flowering during the beginning of the dry season at the time most of the trees were leafless or leaf flushing stage. As flower initiation can advertise to pollinators as they get pollinated as seen in other tropical forest (Murali and Sukumar, 1994; Sundarapandian et al., 2005). Whereas in Costa Rica rainfall (wet season) play a role in flower initiation (Opler et al., 1976).

Reproductive phenological studies in seasonal tropical forest ecosystems have indicated rainfall seasonality as being the fruiting periodicities (De Lampe et al., 1992; White, 1994; Sun et al., 1996; Justiniano and Fredericksen, 2000; Borchert et al., 2004; Nanda et al., 2010). Van Schaik et al., (1993) deduced that leaf flushing and flowering fell within 1 month before the onset of the rainiest period in strongly seasonal forests. In deciduous trees, anthesis can be induced by the temporal rehydration of the trees after leaf fall by isolated rainfall during the dry season or by the onset of the wet season (Reich and Borchert, 1984).

For these reasons, it has been assumed that water availability is both the proximate and the ultimate factor controlling phenology in tropical dry forest plants (Reich and Borchert, 1984). The timing of synchronous flowering in individual species of tropical trees and the resulting flowering 
periodicity at the community level are widely thought to have evolved as a result of biotic interactions between trees and their pollinators (Borchert et al., 2004).

The duration of fruit maturation was longest in dry forest from August to April (monsoon to pre-monsoon period) with a peak in November to January (Nanda et al., 2009). This pattern is in agreement with other tropical studies (Murali and Sukumar, 1994; Sundarapandian et al., 2005). However in evergreen forest the Fruit maturation was from January to July with a peak in the month of April. Maturation was more in pre-monsoon and lessens after a monsoon.

However, tropical wet forests exhibit a wide range of fruiting patterns, including unimodal or bimodal fruiting peaks (Zhang and Wang, 1995; Hamann, 2004). Some tropical dry forest plant phenology studies describe a single fruiting peak related to the dry season or several peaks in the wet and dry seasons (Bullock and Solis-Magallanes, 1990).

\section{Acknowledgements}

We thank Department of Environment, Ministry for Environment and Forests, Government of India for funding this project. We also thank Forest Department of Karnataka for permission to work in Bhadra sanctuary.

\section{References}

Bhat, D.M. 1992. Phenology of tree species of tropical moist deciduous forest of Uttara Kannada district, Karnataka, India. Journal of Bioscience 17: 325352.

Borchert, R., G. Rivera and W. Hagnauer 2002. Modification of vegetative phenology in a tropical semi deciduous forest by abnormal drought and rain. Biotropica 34: 27-39.
Borchert, R., S.A. Meyer, R.S. Felger and L. PorterBolland 2004. Environmental control of flowering periodicity in Costa Rican and Mexican tropical dry forests. Global Ecology and Biogeogrphy 13: 409-425.

Bullock, S.H. and J.A. Solis-Magallanes 1990 Phenology of canopy trees of a tropical deciduous forest in México. Biotropica 22: 22-35.

Champion, H.G. and S.K. Seth 1968. A revised survey of the forest types of India. Govt. of India Press. 404p.

De Lampe, M.G., Y. Bergeron, R. Mcneil and A. Leduc 1992. Seasonal flowering and fruiting patterns in tropical semi-arid vegetation of Northeastern Venezuela Biotropica 24: 64-76.

Gamble, J.S. and C.F.C. Fischer 1998. Flora of the presidency of madras. Adlard and Son, Ltd, 21, Hart Street, W.C. Vol. 1-3, 2017p.

Hamann, A. 2004. Flowering and fruiting phenology of a Philippine submontane rain forest: Climatic factors as proximate and ultimate causes. Journal of Ecology 92: 24-31.

Justiniano, M.J. and T.S. Fredericksen 2000. Phenology of tree species in Bolivian dry forests. Biotropica 32: 276-281.

Krishnamurthy, Y.L., H.M. Prakasha, A. Nanda, M. Krishnappa, H.S. Dattaraja and H.S. Suresh 2010. Vegetation structure and floristic composition of a tropical dry deciduous forest in Bhadra Wildlife Sanctuary, Karnataka, India. Tropical Ecology 51(2): 235-246.

Kushwaha, C.P. and K.P. Singh 2005. Diversity of leaf phenology in a tropical deciduous forest in India. Journal of Tropical Ecology 24: 47-56.

McLaren, K.P. and M.A. McDonald 2003. Seedling dynamics after different intensities of human disturbance in a tropical dry limestone forest in Jamaica. Journal of Tropical Ecology 19: 567578.

Murali, K.S. and R. Sukumar 1994. Reproductive phenology of a tropical dry forest in Mudumalai, southern India. Journal of Ecology 82: 759-767.

Nanda, A., H.M. Prakasha, Y.L. Krishna Murthy and H.S. Suresh 2009. Seasonality, flowering and fruiting patterns in a tropical dry deciduous forest of Bhadra Wildlife Sanctuary, southern India. Functional Plant Science and Biotechnology 3(1): 49-54. 
A. Nanda, H.M. Prakasha, Y.L. Krishna Murthy and H.S. Suresh/Our Nature (2011) 9:89-99

Nanda, A., H.M. Prakasha, Y.L. Krishna Murthy and H.S. Suresh 2010. Phenology of a tropical dry forest: study from Bhadra Wildlife Sanctuary, Karnataka, peninsular India. Indian Journal of Forestry 33(2): 167-172.

Neginhal, S.G. 2004. Forest trees of south India. Navbharath Press, Bangalore. 447p.

Opler, P.A., G.W. Frankie and H.G. Baker 1976. Rainfall as a factor in the release, timing, and synchronization of anthesis by tropical trees and shrubs. Journal of Biogeography 3: 231-236.

Parameshwar, G. 1996. Draft management plan for Bhadra Wildlife Sanctuary (1996-2001), Publication: Wildlife Division, Chikkmagalur, Karnataka Forest Department. 43p.

Raju, R. and S.N. Heggde 1995. Bhadra Wildlife Sanctuary, a fragile ecosystem. Inidan Forester pp. 938-948.

Ralhan, P.K., R.K. Khanna, S.P. Singh and J.S. Singh 1985. Phenological characteristics of the tree layer of Kumaun Himalayan forests. Vegetatio 60: 91101.

Ramaswamy, S.N., M.R. Rao and D.A. Govindappa 2001. Flora of Shimoga district, Karnataka. Prasaranga University of Mysore, Manasagangotri, Mysore. 753p.

Rathcke, B. and E.P. Lacey 1985. Phenological patterns of terresterial plants. Annual Review of Ecology and Systamatics 16: 179-214.

Reich, P.B. and R. Borchert 1984. Water stress and tree phenology in a tropical dry forest in the lowlands of Costa Rica. Journal of Ecology 72: 61-74.

Saha, S. 2007. Study of leafing, flowering and fruiting activities in three species of temperate forest at the Singalila range, Darjeeling. Indian Journal of Ecology 34: 15-18.

Saldhana, C.J. 1984-1996. Flora of Karnataka. Vol. IIV. Oxford and IBH Publishing Co. Pvt. Ltd., New Delhi. 839p.

Shukla, R.P. and P.S. Ramakrishnan 1982. Phenology of trees in sub-tropical humid forest in northeastern India. Vegetatio 49: 103-109.

Singh, K.P. and C.P. Kushwaha 2005. Emerging paradigms of tree phenology in dry tropics. Current Science 89: 964-975.
Sun, C., B.A. Kaplin, K.A. Kristensen, V. Munyaligoga, J. Mvukiyumwami, K.K. Kajondo and T.C. Moermond 1996. Tree phenology in a tropical montane forest in Rwanda. Biotropica 28: 668-681.

Sundarapandian, S.M., S. Chandrashekaran and P.S. Swamy 2005. Phenological behaviour of selected tree species in tropical forests at kodayar in the Western Ghats, Tamilnadu, India. Current Science 88: $805-810$.

Symthe, N. 1970. Relationships between fruiting seasons and seed dispersal methods in a neotropical forest. American Naturalist 104: 25 36.

Van Schaik, C.P., J.W. Terborgh and S.J. Wright 1993. The phenology tropical forests: significance and consequences for primary consumers. Annual Review of Ecology and Systamatics 24: 333-357.

Walter, H. 1971. Ecology of tropical and subtropical vegetation. Oliver and Boyd, Edinburgh.

White, L.J.T. 1994. Patterns of fruit-fall in the Lope reserve, Gabon. Journal of Tropical Ecology 10: 289-312.

Williams-Linera, G. 1999. Leaf dynamics in a tropical cloud forest: phenology, herbivory, and life span. Selbyana 20: 98-105.

Wright, S.J. 1996. Phenological responses to seasonality in tropical forest plants. In Tropical forest ecophysiology. New York, Chapman and Hall. pp. 440-460.

Wright, S.J. and C.P. Van Schaik 1994. Light and the phenology of tropical trees. American Naturalist 143: $192-199$

Yoganarasimhan, S.N., K. Subramanyam and B.A. Razi 1982. Flora of Chikkamagalur district, Karnataka, India. International Book Distributors, Deharadun. 407p.

Zar, J. 2007. Biostatistical analysis. Pearson Education (Singapore) Pvt. Ltd. 663p.

Zhang, S. and L. Wang 1995. Comparison of three fruit census methods in French Guiana. Journal of Tropical Ecology 11: 281-294. 